\title{
The effects of differential compaction on clinothem geometries and shelf-edge trajectories
}

\author{
Daan Beelen 1,2, Christopher A.-L. Jackson', Stefano Patruno ${ }^{3}$, David M. Hodgson ${ }^{4}$ and João P. Trabucho Alexandre ${ }^{2}$ \\ ${ }^{1}$ Basins Research Group (BRG), Department of Earth Sciences and Engineering, Imperial College, London SW7 2AZ, UK \\ 2Department of Earth Sciences, Universiteit Utrecht, P.O. Box 80115, 3508 TC Utrecht, Netherlands \\ 3PGS, 4 The Heights, Brooklands, Weybridge, Surre, KT13 ONY, UK \\ ${ }^{4}$ School of Earth and Environment, University of Leeds, Leeds LS2 9JT, UK
}

\begin{abstract}
The geometry of basin-margin strata documents changes in water depth, slope steepness, and sedimentary facies distributions. Their stacking patterns are widely used to define shelfedge trajectories, which reflect long-term variations in sediment supply and relative sea-level change. Here, we present a new method to reconstruct the geometries and trajectories of clinoform-bearing basin-margin successions. Our sequential decompaction technique explicitly accounts for downdip lithology variations, which are inherent to basin-margin stratigraphy. Our case studies show that preferential compaction of distal, fine-grained foresets and bottomsets results in a vertical extension of basin-margin strata and a basinward rotation of the original shelf-edge trajectory. We discuss the implications these effects have for sea-level reconstructions and for predicting the timing of sediment transfer to the basin floor.
\end{abstract}

\section{INTRODUCTION}

Clinoforms are a characteristic geometry of basin-margin strata (Rich, 1951). Rock units between clinoforms are called clinothems, and during progradation these strata stack laterally (and in some cases subvertically) to form basinmargin successions (e.g., Patruno and HellandHansen, 2018). Clinothem geometries are widely used to infer basin depth, slope steepness, and progradation rates, as well as sedimentary facies distributions, the timing of shelf incision and sediment bypass, and past changes in climate and sea level (e.g., Patruno et al., 2015a, 2015b). A key aspect of this analysis is recognition and mapping of the shelf-edge trajectory, which provides a record of the shelf-to-slope rollover position through time in a basin-margin clinothem succession (Fig. 1). Theoretically, such trajectories are proportional to the ratio of sediment aggradation to progradation, and they can be used to infer relative changes in sediment supply and sea level (Haq et al., 1987; Helland-Hansen and Hampson, 2009). Different styles of shelf-edge trajectory have been associated either with enhanced sediment storage on shelves (rising trajectory) or with increased sediment bypass and deposition on the basin floor (flat to falling trajectory). However, ancient basin-margin successions are, or have been, buried below younger sediments, and their clinothem geometries and associated trajectories have been distorted by sediment loading and compaction; this distortion does not recover if the succession is exhumed. To account for this, e.g., when estimating paleo-water depth by measuring clinothem heights (e.g., Haq et al., 1987; Plint et al., 2009; Patruno et al., 2015b), previous studies have decompacted the overburden overlying a succession of clinothems (e.g., Plint et al., 2009; Allen and Allen, 2013). We refer to this single-step method as "non-sequential decompaction". Steckler et al. (1999) and Klausen and Helland-Hansen (2018) developed a more complex, multi-step method involving decompaction of each successive clinothem within the succession, from youngest to oldest. We refer to this as "sequential decompaction". Critically, Steckler et al. (1999) used a stratigraphically and spatially uniform "mixed" lithology across clinothems, whereas Klausen and Helland-Hansen (2018) used three computer-processed interpretation logs to distribute lithology linearly down a clinothem. Correctly assigning lithologies to studied clinothems is a key step, as porosity-depth relations for topset, foreset, and bottomset deposits from highresolution well-log data in the Washakie Basin (Wyoming, United States) (Carvajal and Steel, 2011), indicate that the foresets and bottomsets compact twice as much as coarser-grained topsets of the same clinothem when subjected to $3 \mathrm{~km}$ of burial (Carvajal and Steel, 2011; Item DR1 in the GSA Data Repository1). The numerical models of Prince and Burgess (2013) developed this idea, showing that differential compaction may cause a reorientation of the shelf-edge trajectory. However, this has not been demonstrated in real-world examples of basin-margin successions comprising multiple clinothems with downdip variations in lithology.

We quantify how downdip variations in clinothem lithology drive differential compaction, and how this modifies clinothem heights, slope gradients, and trajectories in basin-margin successions. We do this by applying our sequential decompaction workflow to a broad suite of basin margins, sampled by different data types, to reconstruct their pre-burial, undistorted geometries and trajectories; i.e., we use depth-converted seismic reflection (Taranaki Basin, New Zealand; Anell and Midtkandal, 2017), well-log (Washakie Basin, Wyoming; Carvajal and Steel, 2011), and outcrop data sets (Van Keulenfjorden, Norway; Steel and Olsen, 2002) to reconstruct pre-burial clinothem trajectories. Finally, we discuss the implications of burial-induced geometric distortion of basin margins.

${ }^{1}$ GSA Data Repository item 2019360, Item DR1 (extended methodology), Item DR2 (extended results), and Item DR3 (decompaction animation), is available online at http://www.geosociety.org/datarepository/2019/, or on request from editing@geosociety.org.

CITATION: Beelen, D., et al., 2019, The effects of differential compaction on clinothem geometries and shelf-edge trajectories: Geology, v. 47, p. 1011-1014, https:// doi.org/10.1130/G46693.1 
A Present-day, no reconstruction B Non-sequential decompaction C
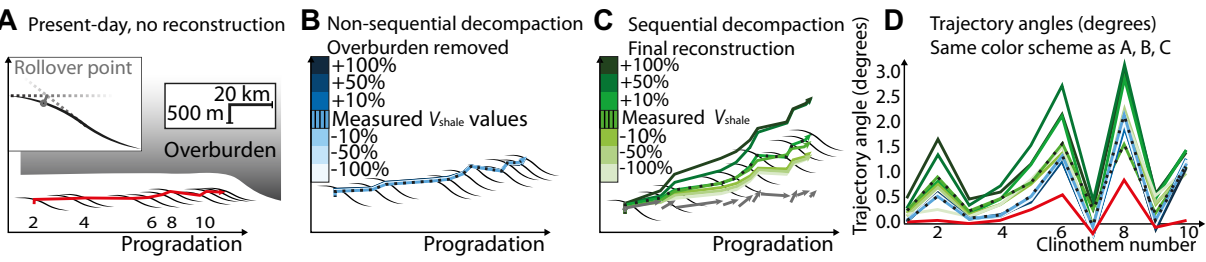

Figure 1. Schematic dip-section of a clinoform-bearing succession in the Washakie Basin, Wyoming, USA (Carvajal and Steel, 2011). A: The present shelf-edge trajectory is shown in red; inset shows placement of the shelf-slope rollover point. B: Non-sequentially decompacted trajectory (blue). C: Sequentially decompacted trajectory (green), with unassembled trajectory increments shown as gray arrows. D: Trajectory angles for each clinothem in succession from 1 to 10 . Sand/shale ratio $\left(V_{\text {shae }}\right)$ values for each topset, foreset, and bottomset compartment within each clinothem are from Carvajal and Steel (2012). Color gradients in B and C correspond to varying $V_{\text {shale }}$ inputs. Note low sensitivity to $V_{\text {shale }}$ in non-sequential decompaction (blue) and high sensitivity in sequential decompaction (green).

\section{METHODS}

We model clinothem rock volumes with spatial differences in sandstone and claystone by assigning $V_{\text {shale }}(\mathrm{sand} / \mathrm{shale}$ ratio) values $(0=$ clean sandstone consisting of rounded sand grains; 1 = claystone consisting of plate-shaped clay grains) (see Item DR1 for the methodology). This is a widely used but simplified approach to capture variable compaction behaviors of clay minerals and silt grain types (Giles et al., 1998). Here, $V_{\text {shale }}$ values for proximal topsets and more distal foresets and bottomsets are obtained from literature or, where available, directly from well$\log$ or outcrop data (Johannessen et al., 2011; Carvajal and Steel, 2011). A porosity-depth coefficient is then calculated for each topset, foreset, and bottomset "compartment" within every clinothem, using the porosity-depth relations of Sclater and Christie (1980). We then backstrip (cf. Allen and Allen, 2013), decompact, and unload all material overlying the target succession ("non-sequential decompaction"; Fig. 1B). This is followed by backstripping, decompaction, and unloading of each clinothem, from youngest to oldest ("sequential decompaction"; Fig. 1C). This two-stage approach recreates the original, unburied geometry for each clinothem. The associated trajectory position and orientation are reconstructed to their pre-burial state. To reconstruct the complete trajectory, each reconstructed trajectory increment is recorded after each sequential decompaction step, and the complete trajectory is assembled by joining all increments (Fig. 1C). This accounts for the effects of continuous load-induced subsidence that vertically displaces each trajectory increment during the deposition of each consecutive clinothem.

We consider the average rate of shelf-edge clinothem deposition ( 1-5 mm/yr; Patruno and Helland-Hansen, 2018), which is approximately equal to, or slower than, isostatic adjustments due to sediment loading ( $1-8 \mathrm{~mm} / \mathrm{yr}$; Ivins et al., 2007). Subsidence is expected to approach isostatic equilibrium on the spatial and temporal scales considered here. In both steps, a paleohorizontal datum, such as a coal bed or topset surface, $100 \mathrm{~m}$ below the base of the succession was set as $0 \mathrm{~m}$ burial (Klausen and HellandHansen, 2018). Our shelf-slope rollover points are the same as those of the authors of the case studies used here; when these are lacking, we New Zealand's North Island. place the rollover point following prior definitions outlined by Beelen (2017) and Klausen and Helland-Hansen (2018). To examine how lithological uncertainty impacts the calculated shelf-edge trajectory, we perform sensitivity analysis by varying $V_{\text {shale }}$ inputs by $\pm 10 \%$, $\pm 50 \%$, and $\pm 100 \%$ (Fig. 1). More methodology information is in Item DR1.

\section{RESULTS}

We assess our workflow by comparing the reconstructed geometry of a buried clinothem to that of a nearby, unburied-and thus largely undeformed-clinothem in the same formation (Giant Foresets Formation, Taranaki Basin, offshore New Zealand; Fig. 2). For this reconstruction, we use publicly available lithological data from nearby wells. The reconstructed (Fig. 2C) and unburied (Fig. 2D) clinothems have similar heights and slope gradients,

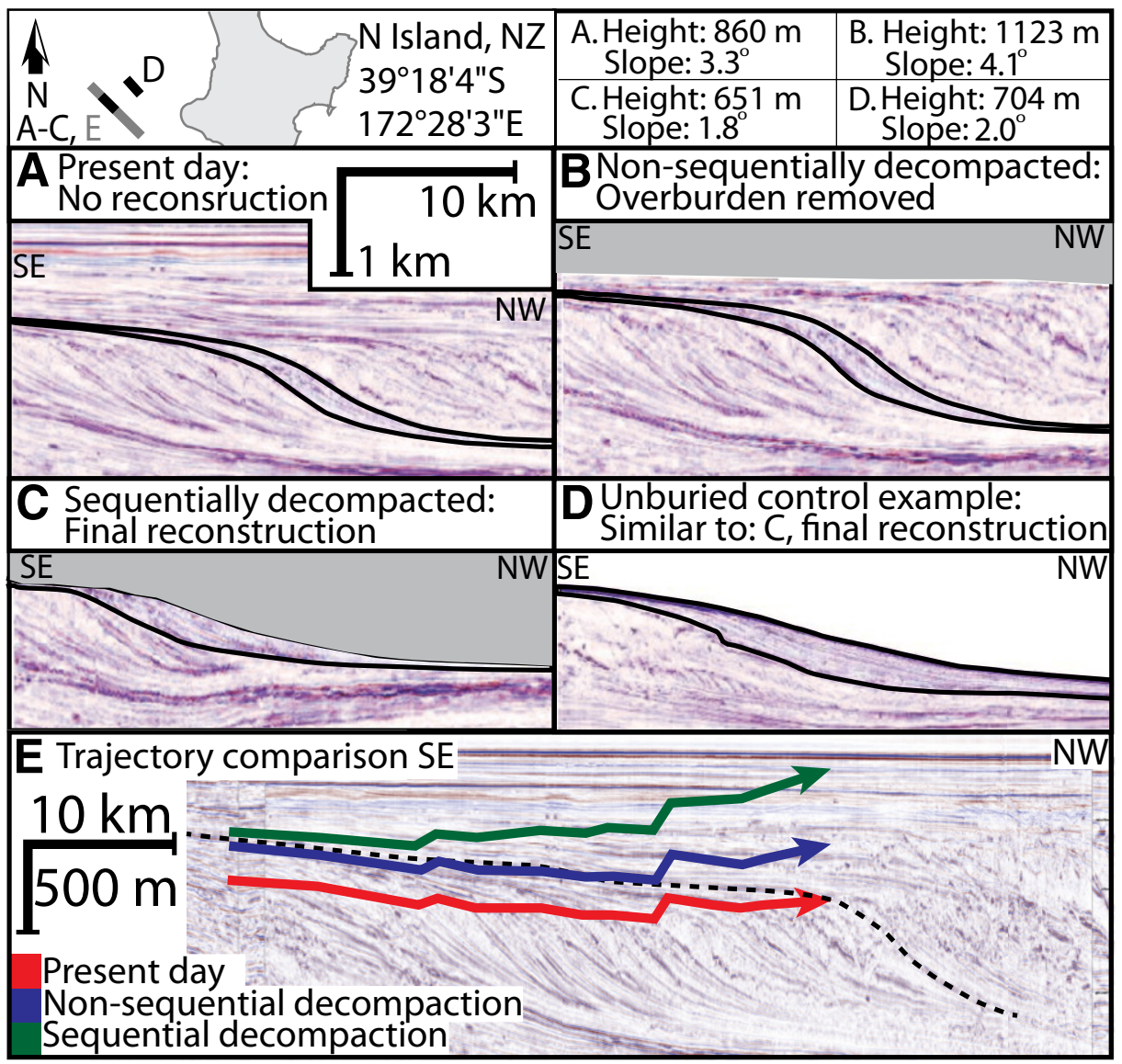

Figure 2. A-C: Geometry of a buried clinothem in the Taranaki Basin (offshore New Zealand [NZ]) at present day (A), and following the two-step approach for restoring the original geometry (B,C). D: Unburied clinothem located $60 \mathrm{~km}$ northeast of A, from the same formation (Giant Foresets Formation). E: Comparison of shelf-edge trajectories for geometries shown in A (red), B (blue), and C (green). Backgound in panels A-E are extracts from a seismic reflection dataset. Dashed line in $E$ represents the most distal clinoform interpreted on this profile. Gray infill in B and $C$ shows backstripped area. Numbers at top right are clinothem height and slope gradient for panels A-D. Non-sequential decompaction with downdip variation in lithology (i.e., from A to B) uniformly increases the height and slope gradient, whereas additional sequential decompaction, accounting for downdip variation in lithology (i.e., from $B$ to C), decreases clinothem heights and slope gradients and results in better similarity with unburied geometry (D). Scale bars shown in A apply to B, C, and D. Image shows coastline of 
suggesting that our method accurately reconstructs the overall geometry, internal architecture, and trajectory of the now-buried clinothem as it would have been in its unburied state.

Clinothem geometries and their trajectory increments respond differently to the two steps of our decompaction workflow. Non-sequential decompaction (step 1) uniformly increases clinothem heights, slope gradients, and trajectory gradients (from Fig. 2A to Fig. 2B). Although additional strata are backstripped during sequential decompaction (step 2), clinothem heights and slope gradients typically decrease rather than increase (from Fig. 2B to Fig. 2C). Overall, we show that after non-sequential and then sequential decompaction, average trajectory gradients are increased by $0.5^{\circ}-1.3^{\circ}$. As a result, many trajectories presently interpreted as being falling or flat may actually have been rising prior to burial-related compaction. For example, the Giant Foresets Formation currently shows an apparent falling shelf-edge trajectory (red arrow in Fig. 2E); our reconstruction shows that, during deposition, a large interval of the shelf-edge trajectory was actually rising (green arrow in Fig. 2E). This interpretation of a syndepositional rising trajectory is independently supported by the thick topset deposits, a stratigraphic architecture generally associated with rising rather than falling trajectories (Helland-Hansen and Hampson, 2009). We applied our workflow to other data sets presently defined by overall falling trajectories (i.e., Columbus Basin, Trinidad: Chen et al. 2016; Karoo Basin, South Africa: Poyatos-Moré et al., 2016). After decompaction, most increments presently defining flat or falling trajectories were reoriented to reveal rising trajectories (Items DR2 and DR3).

\section{DISCUSSION}

We recognize two distinct stages in the burial and compaction of clinothems: (1) "early", sequential compaction, which drives major differential compaction (i.e., compaction increase downdip into areas comprising finer-grained sediment); and (2) "late", non-sequential com-

paction, which is associated with only minor differential compaction (Fig. 3). During the sequential compaction stage, a basinward-fining clinothem is buried by a younger clinothem, and clay-rich foresets and bottomsets compact more than the sandier topsets. This results in a steepening of the foreset strata and, somewhat counterintuitively, an increase in clinothem height (Fig. 3A). This vertical extension arises due to preferential compaction of the bottomsets that is, in most cases, greater than the overall compaction of the clinothem, causing a net increase in clinothem height and slope (from Fig. $2 \mathrm{C}$ to Fig. 2B). Also, topset surfaces, used to estimate paleohorizontal datums, are tilted basinward due to differential compaction. Continuous load-induced subsidence results in accommodation creation and the deposition of strata associated with net-rising trajectories, even during relative sealevel fall. These effects are likely ubiquitous, because the key driver for differential compaction is the intrinsic basinward fining of clinothems (Rich, 1951). During the "late", non-sequential compaction stage, when the clinoform-bearing succession has been deposited and is subsequently buried, the amount of differential compaction is much less than in the first, sequential compaction stage. This is because as clinothems prograde into the basin, they stack laterally to form parallel belts of similar lithology (i.e., coarser topset and finer foreset and bottomset compartments are roughly horizontally aligned; Fig. 3B). Additional burial then drives non-differential compaction, which decreases clinothem heights and slope gradients by evenly compressing the entire succession (Fig. 3B).

The two stages of compaction also have a different effect on the shelf-edge trajectory. Sequential compaction first causes a downward rotation of the trajectory due to differential compaction (Fig. 3A). Non-sequential compaction then, approximately uniformly, compresses the entire succession, thereby reducing the gradients of rising trajectories (Fig. 3B). The decline in differential compaction between the two stages of compaction can also be observed in the results of our sensitivity analyses, which

A Sequential compaction

Major differential compaction

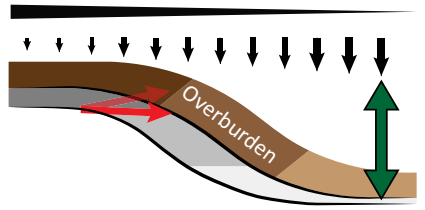

Change in trajectory orientation

Extension in height and slope gradient
B Non-sequential compaction

Minor differential compaction

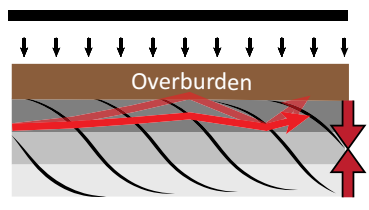

Reduction in trajectory gradient Reduction in height and slope gradient
Figure 3. Impacts of "early", differential (i.e., sequential) compaction (A) and "late", non-differential (i.e., non-sequential) compaction (B) on clinothem geometries and shelf-edge trajectories. Topset, foreset, and bottomset compartments are indicated in gray shading; black bars represent grainsize trends. Note the opposing effects with respect to clinothem height (decreases) and slope gradient (increases). In this simplified example, we assume roughly equal deposition across the surface of a buried clinothem. Following the non-sequential stage (Fig. 2B), there may be further basinward tilting of succession due to loading with respect to the proximal hinge point and thermal subsidence. indicate that the initial sequential compaction stage is sensitive to lithological inputs (i.e., large divergence in results in Figs. 1C and 1D, green lines). In contrast, non-sequential compaction proceeds virtually irrespective of $V_{\text {shale }}$ inputs (small divergence in results; Figs. 1B and $1 \mathrm{D}$, blue lines), despite $\sim 10 \times$ more material being removed in the non-sequential decompaction step. We note that how much a trajectory is reoriented after burial is dependent on not only the rate of basinward fining, but also the size and shape of the overlying clinothem. For instance, in the case of significant progradation, more material is placed on the distal part of the underlying strata, causing additional rotation. The amount of reorientation is also affected by differences in the thicknesses of the underlying topset foreset or bottomset strata, because this controls how much material is available for compaction. Clinothems associated with steeply rising trajectories would not be aligned horizontally, as younger units would be placed diagonally above older units. When this is the case, downdip lithological changes would persist, though less prominently, as indicated by our sensitivity analyses that shows very low sensitivity to lithological inputs for a rising trajectory (Fig. 1B; see also Item DR3). The two stages of compaction work in opposition, whereby the early sequential stage causes an increase in clinothem heights and slope gradients whereas non-sequential compaction causes a decrease (Fig. 2). Deibert et al. (2003) argued the opposite, stating that differential compaction decreases the height and slope gradient of the clinothem. We suggest that the reason for this discrepancy arises because they did not include downdip changes in grain size within their decompacted clinothems. We thus argue that the effects of lithology-induced differential compaction within clinothems and the distinction between sequential and non-sequential compaction are essential concepts for recognizing, reconstructing, and quantifying the geometry and evolution of basin-margin successions. Appreciating these effects can significantly improve our ability to accurately constrain progradation rates and depositional fluxes (e.g., Patruno et al., 2015b), paleoclimate reconstructions (e.g Steckler et al., 1999), sea-level fluctuations (e.g., Haq et al., 1987), and paleoslope gradients (e.g., Deibert et al., 2003). Finally, it is important to note that basinward tilting of the entire basin-margin succession, during and after sequential compaction, may occur in response to thermal subsidence and/or uplift of the basin margin.

\section{CONCLUSIONS}

We reconstruct the geometries and trajectories of basin-margin successions, explicitly accounting for differential compaction due to lithological heterogeneities within clinothem 
rock volumes and isostatic loading due to the weight of the clinothems. We show that clinothem heights and slope gradients measured from buried successions are significantly different from their original, pre-burial depositional geometries. Potentially major reorientations of the original basin-margin trajectory can occur, causing the present trajectory to differ from the ratio between aggradation and progradation. Rising trajectories can be reoriented to appear as a falling trajectory, a key notion relevant for improving our ability to reconstruct relative and eustatic sea level. Burial-related geometric distortion of clinothems and trajectories occurs in two distinct stages: sequential, then non-sequential. Each stage has a roughly opposite net effect to the height and slope gradient of the clinothem. These results are relevant to many important factors associated with basin-margin analysis like progradation rates and depositional fluxes, paleoclimate reconstructions, sea-level fluctuations, and paleoslope gradients.

\section{ACKNOWLEDGMENTS}

We thank the reviewers Ingrid Anell, Cornel Olariu, Tore Klaussen, Peter Burgess, Christian Haug-Eide, Ron Steel, Andrea Fildani, and Ivar Midtkandal, and the editor James Schmitt, for their essential role in the making of this paper. We also thank the European Union's Eramus+ program for partially funding the research. Finally, we thank GNS Science for making the Taranki Basin seismic data publically available.

\section{REFERENCES CITED}

Allen, P.A., and Allen, J.R., 2013, Basin Analysis: Principles and Application to Petroleum Play Assessment (third edition): New York, John Wiley \& Sons, $632 \mathrm{p}$.

Anell, I., and Midtkandal, I., 2017, The quantifiable clinothem-Types, shapes and geometric relationships in the Plio-Pleistocene Giant Foresets Formation, Taranaki Basin, New Zealand: Basin Research, v. 29, p. 277-297, https:// doi.org/10.1111/bre.12149.

Beelen, D., 2017, The effect of differential compaction on shelf-edge trajectories [M.S. thesis]: Utrecht, Utrecht University, $65 \mathrm{p}$.

Carvajal, C., and Steel, R., 2012, Source-to-sink sediment volumes within a tectono-stratigraphic model for a Laramide shelf-to-deepwater basin: Methods and results, in Busby,
C., and Azor, A., eds., Tectonics of Sedimentary Basins: Recent Advances: London, Blackwell Publishing Ltd, p. 131-151, https://doi .org/10.1002/9781444347166.ch7.

Chen, S., Steel, R.J., and Olariu, C., 2016, Upperslope to shelf-edge delta architecture, Miocene Cruse Formation, Orinoco shelf margin, Trinidad: Journal of Sedimentary Research, v. 86, p. 87106, https://doi.org/10.2110/jsr.2016.7.

Deibert, J.E., Benda, T., Løseth, T., Schellpeper, M., and Steel, R.J., 2003, Eocene clinoform growth in front of a storm-wave-dominated shelf, Central Basin, Spitsbergen: No significant sand delivery to deepwater areas: Journal of Sedimentary Research, v. 73, p. 546-558, https://doi .org/10.1306/011703730546.

Giles, M.R., Indrelid, S.L., and James, D.M.D., 1998, Compaction-The great unknown in basin modelling, in Düppenbecker, S.J., and Iliffe, J.E., eds., Basin Modelling: Practice and Progress: Geological Society, London, Special Publications, v. 141 , p. $15-43$, https://doi.org/10.1144/GSL. SP.1998.141.01.02.

Haq, B.U., Hardenbol, J.A.N., and Vail, P.R., 1987, Chronology of fluctuating sea levels since the Triassic: Science, v. 235, p. 1156-1167, https:// doi.org/10.1126/science.235.4793.1156.

Helland-Hansen, W., and Hampson, G.J., 2009, Trajectory analysis: Concepts and applications: Basin Research, v. 21, p. 454-483, https://doi .org/10.1111/j.1365-2117.2009.00425.x.

Ivins, E.R., Dokka, R.K. and Blom, R.G., 2007, Postglacial sediment load and subsidence in coastal Louisiana: Geophysical Research Letters, v. 34, L16303, https://doi.org/10.1029/2007GL030003.

Johannessen, E.P., Henningsen, T., Bakke, N.E., Johansen, T.A., Ruud, B.E., Riste, P., Elvebakk, H., Jochmann, M., Elvebakk, G., and Woldengen, M.S., 2011, Palaeogene clinothem succession on Svalbard expressed in outcrops, seismic data, logs and cores: First Break, v. 29, no. 2, p. 35-44, https://doi.org/10.3997/1365-2397.2011004.

Klausen, T.G., and Helland-Hansen, W., 2018, Methods for restoring and describing ancient clinoform surfaces: Journal of Sedimentary Research, v. 88, p. 241-259, https://doi.org/10.2110/jsr.2018.8.

Patruno, S., and Helland-Hansen, W., 2018, Clinoform systems: Review and dynamic classification scheme for shorelines, subaqueous deltas, shelf edges and continental margins: EarthScience Reviews, v. 185, p. 202-233, https://doi .org/10.1016/j.earscirev.2018.05.016.

Patruno, S., Hampson, G.J., Jackson, C.A.-L., and Whipp, P.S., 2015a, Quantitative progradation dynamics and stratigraphic architecture of ancient shallow-marine clinoform sets: A new method and its application to the Upper Jurassic
Sognefjord Formation, Troll Field, offshore Norway: Basin Research, v. 27, p. 412-452, https:// doi.org/10.1111/bre.12081.

Patruno, S., Hampson, G.J., and Jackson, C.A.-L., 2015b, Quantitative characterisation of deltaic and subaqueous clinothems: Earth-Science Reviews, v. 142, p. 79-119, https://doi.org/10.1016/ j.earscirev.2015.01.004.

Plint, A.G., Tyagi, A., Hay, M.J., Varban, B.L., Zhang, H., and Roca, X., 2009, Clinothems, paleobathymetry, and mud dispersal across the Western Canada Cretaceous foreland basin: Evidence from the Cenomanian Dunvegan Formation and contiguous strata: Journal of Sedimentary Research, v. 79, p. 144-161, https://doi.org/10.2110/ jsr.2009.020.

Poyatos-Moré, M., Jones, G.D., Brunt, R.L., Hodgson, D.M., Wild, R.J. and Flint, S.S., 2016, Muddominated basin-margin progradation: Processes and implications: Journal of Sedimentary Research, v, 86, p. 863-878, https://doi.org/10.2110/ jsr.2016.57.

Prince, G.D., and Burgess, P.M., 2013, Numerical modeling of falling-stage topset aggradation: Implications for distinguishing between forced and unforced regressions in the geological record: Journal of Sedimentary Research, v. 83, p. 767-781, https://doi.org/10.2110/jsr.2013.62.

Rich, J.L., 1951, Three critical environments of deposition, and criteria for recognition of rocks deposited in each of them: Geological Society of America Bulletin, v. 62, p. 1-20, https://doi.org/10.1130/00167606(1951)62[1:TCEODA]2.0.CO;2.

Sclater, J.G., and Christie, P.A.F., 1980, Continental stretching; An explanation of the post-MidCretaceous subsidence of the central North Sea basin: Journal of Geophysical Research, v. 85 , p. 3711-3739, https://doi.org/10.1029/ JB085iB07p03711.

Steckler, M.S., Mountain, G.S., Miller, K.G., and Christie-Blick, N., 1999, Reconstruction of Tertiary progradation and clinothem development on the New Jersey passive margin by 2-D backstripping: Marine Geology, v. 154, p. 399-420, https://doi.org/10.1016/S0025-3227(98)00126-1.

Steel, R., and Olsen, T., 2002, Clinoforms, clinoform trajectories and deepwater sands, in Armentrout, J.M., and Rosen, N.C., eds., Sequence Stratigraphic Models for Exploration and Production: Evolving Methodology, Emerging Models and Application Histories: Proceedings of the Gulf Coast Section SEPM Foundation 22nd Annual Bob. F. Perkins Research Conference: Houston, Texas, Gulf Coast Section SEPM (Society for Sedimentary Geology), p. 367-381.

Printed in USA 